$1-1-1963$

\title{
The available molybdenum status of some West Virginia soils
}

\author{
Kenneth L. Stone \\ Everett M. Jencks
}

Follow this and additional works at: https://researchrepository.wvu.edu/ wv_agricultural_and_forestry_experiment_station_bulletins

\section{Digital Commons Citation}

Stone, Kenneth L. and Jencks, Everett M., "The available molybdenum status of some West Virginia soils" (1963). West Virginia Agricultural and Forestry Experiment Station Bulletins. 484.

https://researchrepository.wvu.edu/wv_agricultural_and_forestry_experiment_station_bulletins/454 @ WVU. It has been accepted for inclusion in West Virginia Agricultural and Forestry Experiment Station Bulletins by an authorized administrator of The Research Repository @ WVU. For more information, please contact ian.harmon@mail.wvu.edu. 
30. S.

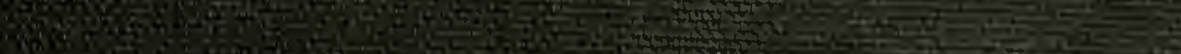
3.

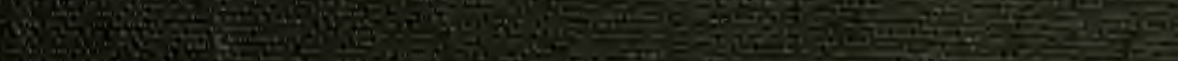

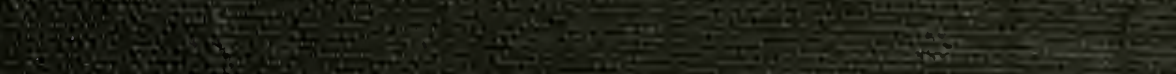
on's

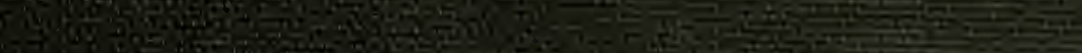
S.

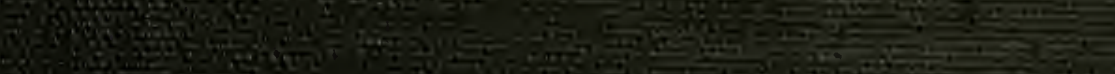

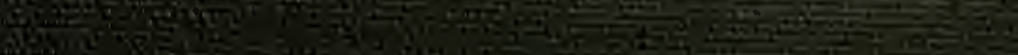
A 4a

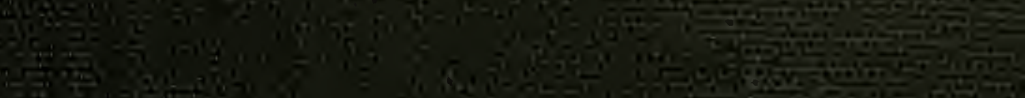
6.9. स은 Wh: $40+50$ 은 $\cos 20$ - 
Digitized by the Internet Archive in 2010 with funding from

Lyrasis Members and Sloan Foundation 


$$
\text { not } 1 \text { troinia Untvergity }
$$

JUNE 1963

\section{The Available}

Molybdenum Status
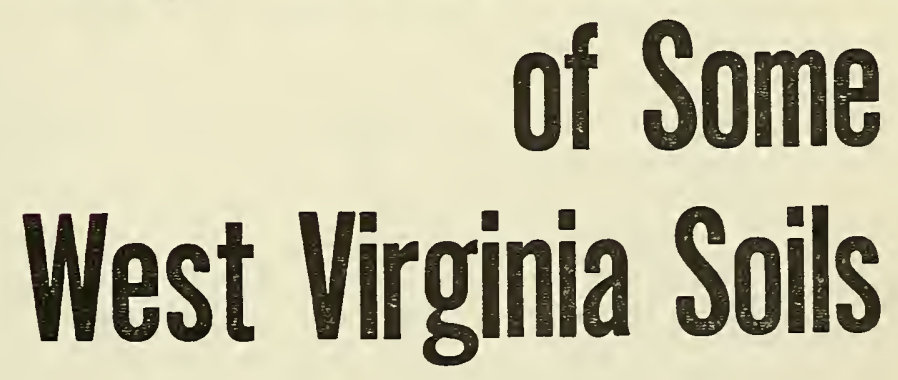


\section{THE AUTHORS}

The authors of The Available Molybdenum Status of Some West Virginia Soils are Kenneth L. Stone, former Graduate Assistant in the West Virginia University Agricultural Experiment Station, and Everett M. Jencks, Assistant Experiment Station Agronomist.

The information in this Bulletin is based on portions of the thesis submitted by Kenneth L. Stone in partial fulfillment of the requirements for the Master of Science degree.

WEST VIRGINIA UNIVERSITY

Agricultural Experiment Station

College of Agriculture, Forestry, and Home Economics

A. H. Vanlandingham, Director

MORGANTOWN 


\section{The Available Molybdenum Status of Some West Virginia Soils}

K. L. STONE and E. M. JENCKS

OST of the knowledge of the chemical status of molybdenum in soils, and of its relationship to plant growth has evolved quite recently. The principal reason for this is the lack of sufficiently refined analytical methods for determining levels of this nutrient in soils and plant tissue. Molybdenum is found in very small quantities in soils and is required only in trace amounts by plants. Nevertheless, when this nutrient is deficient in soils, crop quality and yields suffer just as much as when nitrogen or some other major nutrient is limiting.

Molybdenum-deficient soils have been found in many areas of the world, and in several areas of the United States (8). In West Virginia the importance of molybdenum in crop production was first recognized in the Canaan Valley, Tucker County. Certain varieties of cauliflower grown on these soils exhibited the molybdenum deficiency symptom referred to as "whiptail." This prompted a study of the molybdenum status of West Virginia soils.

Sperow (9) determined the total molybdenum content of some of the agriculturally-important soils of the State. He found total molybdenum content ranges from $0.42 \mathrm{ppm}$ to $11.70 \mathrm{ppm}$ (parts per million). The information resulting from this study is of value in evaluating the potential of soils to supply molybdenum. However, with molybdenum, as with most other nutrients, there is often little correlation between the total amount in the soil and the amount available to plants.

The determination of available molybdenum by chemical methods is difficult because the amounts present in soils are often below that which can be accurately detected.

Many workers have reported poor correlation between chemical test results of available molybdenum and crop growth in the field. Grigg (3) presented a chemical method, which is time-consuming and suffers from ion interference. Purvis and Peterson (7) improved Grigg's method to some degree.

Several investigators have used biological assay techniques to test for available contents of trace nutrients in soils. Mulder (4) and Gerretsen (2), in Holland, and Nicholas (6) and Nicholas and Fielding (5), in England, using Aspergillus niger as the test organism, analyzed a large number of soils for available molybdenum. These investigators 
found that their bioassay results more accurately reflected the availability of molybdenum to crops in the field than did determinations based on chemical extraction and spectrographic methods.

The study reported here was conducted to determine the available molybdenum content of some agriculturally-important West Virginia soils and to relate the results to total molybdenum content. The Aspergillus niger method was chosen over chemical procedures because of the intrinsic limitations of the latter.

\section{Experimental Procedures}

In the Aspergillus niger method, a weighed amount of soil is placed in a flask containing nutrient solution without molybdenum. Flask and contents are then inoculated with Aspergillus niger M. ${ }^{1}$ The cultures are incubated for six days at $30^{\circ} \mathrm{C}$, after which the fungus mycelium is filtered off, dried, and weighed. The amount of mycelium produced is taken to be proportional to the amount of available molybdenum in the soil added to the flask.

A calibration curve is constructed relating mycelium produced to molybdenum contents of a series of cultures containing known amounts of molybdenum. The available molybdenum of a soil is determined by comparing mycelial weights produced in the test sample with those produced in the standard molybdenum cultures. In calibrating this method, values for quadruplicate samples were found to be in the five per cent error range.

Soil samples were collected by staff members of the Department of Agronomy and Genetics of West Virginia University and by soil scientists of the Soil Conservation Service. Samples were selected from areas that had not been fertilized or limed. Samples for analysis were air-dried, ground, and passed through a 60-mesh sieve. Descriptions of these soils are given in the Appendix. Seventy-five soil samples from 30 different soil series were bioassayed for total molybdenum. Results, averages of triplicate samples, are reported in Table 1.

\section{Results}

The available molybdenum contents of individual soil samples are given in the Appendix and average values are given in Table 1.

The results indicate a wide variation in availability of molybdenum in West Virginia soils. Available amounts varied from a low of 0.021 ppm in a Mercer County Litz shaly silt loam, to a high of over $1.0 \mathrm{ppm}$ in an Ohio County Westmoreland silt loam. Because the apparent amount in the latter soil was too high to be measured with precision, the exact amount of available molybdenum could not be ascertained. The average available molybdenum content for all soils was $0.141 \mathrm{ppm}$

${ }^{1}$ Obtained from H. A. Wilson, Department of Plant Pathology, Bacteriology, and En. tomology, West Virginia University Agricultural Experiment Station. 
Table 1. Total and Available Molybdenum, in ppm, of Major West VIRGINIA SOILS.

SOIL SERIFS

\begin{tabular}{|c|c|c|c|}
\hline \multirow[t]{2}{*}{$\begin{array}{l}\text { No. of } \\
\text { SAMPLES }\end{array}$} & \multirow[t]{2}{*}{$\begin{array}{c}\text { AVERAGE } \\
\text { TOTAL Mo* }\end{array}$} & & \multirow{2}{*}{$\begin{array}{c}\text { Average } \\
\text { AvaILable } \\
\text { Mo }\end{array}$} \\
\hline & & HIGH & \\
\hline
\end{tabular}

Well-drained upland soils of Limestone Valley
A. From Limestone
Berkeley silt loam
Berkeley silt loam
Frankstown silt loam
Frederick silt loam

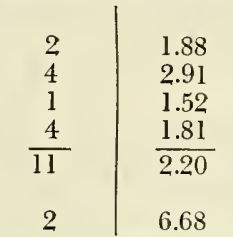

\begin{tabular}{|l|l|l} 
& & \\
0.067 & 0.043 & 0.055 \\
0.304 & 0.127 & 0.214 \\
& & 0.069 \\
0.235 & 0.068 & 0.180 \\
& & 0.153 \\
0.270 & 0.068 & 0.186
\end{tabular}
B. From Shale
Berks silt loam
6.68

\begin{tabular}{c}
\hline I. Well-drained upland soils of the Ridge and Valley Province \\
Ashby silt loam
\end{tabular}

Ashby silt loam
Belmont silt loam
Calvin silt loam
Lehew loam
Litz silt loam
Teas silt loam
Ungers loam

\begin{tabular}{r|l}
4 & 1.02 \\
1 & 1.17 \\
3 & 1.01 \\
3 & 0.97 \\
2 & 0.88 \\
4 & 1.22 \\
$\frac{1}{18}$ & $\frac{0.98}{1.04}$
\end{tabular}

\begin{tabular}{l|l|l}
0.155 & 0.023 & 0.100 \\
& & 0.208 \\
0.109 & 0.091 & 0.099 \\
0.057 & 0.054 & 0.055 \\
0.034 & 0.021 & 0.028 \\
0.178 & 0.064 & 0.114 \\
& & 0.124 \\
& & 0.095
\end{tabular}

II. Well-drained upland soils of the Allegheny Plateau
A. From Limestone and
Shale
Brooke silty clay loam
Westmoreland silt loam
From Sandstone and
Shale
Clymer silt loam
Dekalb silt loam
Gilpin silt loam
Muskingum silt loam
Upshur clay loam
Upshur-Gilpin silty clay
Upshur-muskingum silty clay
Wellston sandy loam
Wharton silt loam

\begin{tabular}{c|l} 
& \\
2 & \\
\hline 3 & 2.34 \\
\hline & 2.78 \\
\hline 3 & 2.49 \\
4 & 1.36 \\
5 & 1.39 \\
3 & 1.74 \\
1 & 1.28 \\
1 & 1.93 \\
2 & 1.76 \\
2 & 1.85 \\
$\frac{3}{24}$ & 0.90 \\
& $\frac{2.15}{1.57}$
\end{tabular}

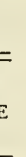


On a group basis, the well-drained upland soils of the Allegheny Plateau, derived from limestone and shale, contained the highest amounts of available molybdenum. Other upland soils derived from limestone or calcareous shales-such as the Hagerstown, Frederick, and Belmont serieswere well above average in available molybdenum content. Although not derived from limestone or calcareous parent material, the Wharton and Berks series tested high in available molybdenum. The Wheeling and Zoar soils occurring on river terraces also contained relatively high amounts of available molybdenum.

As a group, the highly-leached and mature soils listed under miscellaneous slowly-drained upland soils contained the lowest amounts of available molybdenum. Some of the well-drained upland soils of the Ridge and Valley Province and some of the soils from the Allegheny Plateau were also low in available molybdenum. These soils, for the most part, developed from non-calcareous sandstone and shales.

Available molybdenum content was not closely correlated with total molybdenum content. ${ }^{2}$ This indicates that total molybdenum data alone is insufficient to completely evaluate West Virginia soils from the standpoint of meeting actual crop needs. The data show that soils high in total molybdenum tend to be higher in available molybdenum, but the relationship is not proportionate.

\section{Discussion}

Although the bioassay method employed in this work has been found to be dependable by other workers, and was found to be desirable in this study, it can serve only as a general guide for field recommendations. The results must first be correlated with crop growth in the field. Nevertheless, the data obtained can be used to classify the soils investigated with respect to available molybdenum content.

Of the 75 soil samples tested, six would be considered deficient if rated according to standards of Nicholas and Fielding (5), since these six contain less than $0.05 \mathrm{ppm}$ of available molybdenum. They are an Ashby channery loam from Mercer County, a Berkeley clay loam from Berkeley County, a Wellston fine sandy loam from Wayne County, a Tilsit silt loam from Mercer County, and two Litz shaly silt loams, one each from Monroe and Mercer counties.

The Ashby series, developed from gray acid shale and sandstone of Devonian age, are shallow and have very rapid internal drainage. Total molybdenum was also low in the Ashby sample from Mercer County. The low value for available molybdenum content may be related to the mineral composition of the parent material.

Although Berkeley soils are derived from almost pure limestone, which seems to favor higher levels of available molybdenum, only three per cent of the molybdenum in this soil was found to be available.

2The percentage of total molybdenum considered to be available for each soil sample is listed in the Appendix. 
The deep, well-drained Wellston soils are derived from acid Pennsylvanian saridstone and shale. The profile analyzed was low in total molybdenum. This fact, along with relative mature development of this soil series, explains the small amount of available molybdenum found.

Tilsit soils are similar to the Wellston soils in origin, though more highly leached with planosolic profile development. This may account for the small amount of available molybdenum found in the Tilsit sample from Mercer County. Here again, only about three per cent of the total molybdenum was available.

Both of the samples from the well-drained Litz series are low in total molybdenum, which may explain the low available molybdenum contents found in the samples tested.

Twenty-one of the soil samples bioassayed would be considered slightly deficient in available molybdenum, according to Nicholas and Fielding (5). Three samples from the Lehew series, all from Hampshire County, were in this group. Lehew is a shallow soil derived from red Devonian sandstone. Of the three Teas samples investigated, two were slightly deficient. These soils developed on highly weathered, more or less calcareous Mississippian shales on hilly and steep lands, and contain small amounts of total molybdenum. The Teas soils are also shallow and well-drained. The genesis of these soils and their relatively low amounts of total molybdenum may account for the less than average amount of available molybdenum found.

The soils found to be apparently deficient and slightly deficient might, through intensive cropping, produce molybdenum-deficient plants. This would be especially true where the total molybdenum is also at low levels, and where crops with high molybdenum requirements are grown. However, many of these soils are extremely acid, and proper liming would improve their molybdenum status. The length of time that lime would be effective would be determined by the total amount of molybdenum present in each case. Toxicity due to excessive molybdenum is not likely to occur, except perhaps in the case of the Westmoreland silt loam from Ohio County, and then only under certain cropping practices.

\section{Summary and Conclusions}

1. Seventy-five West Virginia soil samples from 30 different soil series were bioassayed for available molybdenum, using Aspergillus niger M. as the test organism.

2. The apparent available molybdenum content of West Virginia soils varied widely. The range was from $0.021 \mathrm{ppm}$ in a Litz shaly silt loam from Mercer County to greater than $1.0 \mathrm{ppm}$ in a Westmoreland silt loam from Ohio County. The average was $0.141 \mathrm{ppm}$.

3. The well-drained upland soils of the Allegheny Plateau contained the highest amount of avilable molybdenum as a group, and the slowly drained upland soils contained the lowest. 
4. Above-average available molybdenum content was associated with soils derived from limestone or calcareous parent material.

5. Soils developed from non-calcareous sandstones and shales were below average in content of available molybdenum, the lowest amounts being found in the more highly weathered and well-drained members of the group.

6. Available molybdenum content was not closely related to total molybdenum content.

According to the bioassay, it appears that molybdenum deficiency may occur on certain soils in West Virginia and certain crops grown on them might benefit from treatment with molybdenum. This would be especially true on soils where total molybdenum is also low. According to Rubens (8), liming these soils would improve the available molybdenum status and might prevent the appearance of deficiencies for some time.

Only one of the soils tested appeared to be high enough in available molybdenum to cause toxicity. Unless this is of more frequent occurrence, crop damage because of excessive available molybdenum is not anticipated.

\section{References Cited}

1. Donald, C., Passey, B. D. and Swaby, R. J., "Bioassay of Several Trace Metals from Australian Soils," Aus. J. Agr. Res., 3:305-326 (1952).

2. Gerretsen, F. C., "On the Use of Aspergillus niger for the Determination of Plant Nutrients in the Soil," Anal. Chim. Acta., 2:782-789 (1948).

3. Grigg, J. L., "The Determination of Available Molybdenum in Soils," New Zealand J. Sci. Technol., A34:405-414 (1953).

4. Mulder, E. G., "The Microbiological Estimation of Copper, Manganese and Molybdenum in Soil and Plant Material," Anal. Chim. Acta., 2:793-800 (1948).

5. Nicholas, D. J. D. and Fielding, A H., "Use of Aspergillus niger as Test Organism for Determining Molybdenum in Soils Available to Crop Plants," Nature, 166:342343 (1950).

6. Nicholas, D. J. D., "Use of Aspergillus niger for Determining Magnesium, Copper, Zinc and Molybdenum in Soils," J. Sci. Food Agic., 1:339-334 (1951).

7. Purvis, E. R. and Peterson, N. K., "Methods of Soil and Plant Analyses for Molybdenum," Soil Sci., 81:223-228 (1956).

8. Rubens, E. J., "Molybdenum Deficiencies in the United States," Soil Sci., 81:191-197 (1956).

9. Sperow, C. B., The Molybdenum Content of West Virginia Soils. W. Va. Univ. Agric. Exp. Sta. Bul. 443, August, 1960. 


\begin{tabular}{|c|c|c|c|c|}
\hline $\begin{array}{c}\text { LABORATORY NUMBER AND } \\
\text { SOIL TYPE }\end{array}$ & $\begin{array}{l}\text { TOTAL } \\
\text { MoLYBDENUM* } \\
\text { PPM }\end{array}$ & $\begin{array}{r}\text { Av } \\
\text { MOL } \\
\text { PF }\end{array}$ & $\begin{array}{l}\text { ILABLE } \\
\text { YBDENUM } \\
\text { PPM } \\
\text { R CENT }\end{array}$ & County \\
\hline $\begin{array}{l}5 \text { Ashby channery loam } \\
6 \text { Ashby shaly silt loam } \\
7 \text { Ashby shaly silt loam } \\
8 \text { Ashby shaly silt loam } \\
12 \text { Belmont silt loam }\end{array}$ & $\begin{array}{l}0.42 \\
1.59 \\
1.06 \\
1.00 \\
1.17\end{array}$ & $\begin{array}{l}0.023 \\
0.092 \\
0.155 \\
0.128 \\
0.208\end{array}$ & $\begin{array}{r}5.40 \\
5.76 \\
15.60 \\
12.81 \\
17.78\end{array}$ & $\begin{array}{l}\text { Mercer } \\
\text { Pocahontas } \\
\text { Randolph } \\
\text { Berkeley } \\
\text { Tucker }\end{array}$ \\
\hline $\begin{array}{l}20 \text { Berkeley clay loam } \\
20 \mathrm{~A} \text { Berkeley clay loam } \\
22 \text { Berks shaly silt loam } \\
23 \text {. Berks shaly silt loam } \\
30 \mathrm{~A} \text { Brooke silt clay loam }\end{array}$ & $\begin{array}{r}2.32 \\
1.43 \\
11.70 \\
1.67 \\
2.64\end{array}$ & $\begin{array}{l}0.067 \\
0.043 \\
0.270 \\
0.101 \\
0.195\end{array}$ & $\begin{array}{l}2.89 \\
3.01 \\
2.31 \\
6.05 \\
7.39\end{array}$ & $\begin{array}{l}\text { Berkeley } \\
\text { Berkeley } \\
\text { Berkeley } \\
\text { Berkeley } \\
\text { Ohio }\end{array}$ \\
\hline $\begin{array}{l}32 \text { Brooke silty clay loam } \\
41 \text { Calvin silt loam } \\
41 \mathrm{~A} \text { Calvin silt loam } \\
42 \text { Calvin silt loam } \\
55 \text { Clymer silt loam }\end{array}$ & $\begin{array}{l}2.05 \\
0.91 \\
1.39 \\
0.72 \\
1.33\end{array}$ & $\begin{array}{l}0.178 \\
0.091 \\
0.109 \\
0.098 \\
0.117\end{array}$ & $\begin{array}{r}8.70 \\
10.00 \\
7.83 \\
13.57 \\
8.78\end{array}$ & $\begin{array}{l}\text { Ohio } \\
\text { Greenbrier } \\
\text { Greenbrier } \\
\text { Tucker } \\
\text { Nicholas }\end{array}$ \\
\hline $\begin{array}{l}56 \text { Clymer fine sandy loam } \\
57 \text { Clymer silt loam } \\
62 \text { Cookport silt loam } \\
69 \text { Dekalb loam } \\
70 \text { Dekalb stony loam }\end{array}$ & $\begin{array}{l}0.97 \\
1.77 \\
0.87 \\
0.59 \\
1.00\end{array}$ & $\begin{array}{l}0.057 \\
0.114 \\
0.063 \\
0.068 \\
0.072\end{array}$ & $\begin{array}{r}5.91 \\
6.42 \\
7.26 \\
11.46 \\
7.18\end{array}$ & $\begin{array}{l}\text { Greenbrier } \\
\text { Upshur } \\
\text { Raleigh } \\
\text { Raleigh } \\
\text { Greenbrier }\end{array}$ \\
\hline $\begin{array}{l}\text { 7:1 Dekalb channery silt loam } \\
72 \text { Dekalb stony silt loam } \\
95 \text { Frankstown silt loam } \\
98 \text { Frederick silt loam } \\
99 \text { Frederick cherty silt loam }\end{array}$ & $\begin{array}{l}2.40 \\
1.56 \\
1.52 \\
1.33 \\
2.25\end{array}$ & $\begin{array}{l}0.212 \\
0.088 \\
0.069 \\
0.068 \\
0.197\end{array}$ & $\begin{array}{l}8.81 \\
5.65 \\
4.54 \\
5.11 \\
8.78\end{array}$ & $\begin{array}{l}\text { Randolph } \\
\text { Preston } \\
\text { Greenbrier } \\
\text { Mercer } \\
\text { Monroe }\end{array}$ \\
\hline $\begin{array}{l}100 \text { Frederick silt loam } \\
101 \text { Frederick stony silt loam } \\
102 \text { Gilpin silt loam } \\
103 \text { Gilpin silt loam } \\
104 \text { Gilpin silt loam }\end{array}$ & $\begin{array}{l}1.67 \\
1.98 \\
1.73 \\
1.40 \\
0.95\end{array}$ & $\begin{array}{l}0.235 \\
0.221 \\
0.213 \\
0.083 \\
0.067\end{array}$ & $\begin{array}{r}14.05 \\
11.16 \\
12.33 \\
5.91 \\
7.03\end{array}$ & $\begin{array}{l}\text { Berkeley } \\
\text { Berkeley } \\
\text { Marshall } \\
\text { Nicholas } \\
\text { Raleigh }\end{array}$ \\
\hline $\begin{array}{l}105 \text { Gilpin silt loam } \\
106 \text { Gilpin silt loam } \\
116 \text { Hagerstown silt loam } \\
117 \text { Hagerstown silt loam } \\
118 \text { Hagerstown stony silt loam }\end{array}$ & $\begin{array}{l}2.48 \\
2.14 \\
2.27 \\
2.30 \\
3.12\end{array}$ & $\begin{array}{l}0.125 \\
0.133 \\
0.297 \\
0.128 \\
0.304\end{array}$ & $\begin{array}{r}5.04 \\
6.20 \\
13.07 \\
5.56 \\
9.76\end{array}$ & $\begin{array}{l}\text { Upshur } \\
\text { Monongalia } \\
\text { Pocahontas } \\
\text { Jefferson } \\
\text { Berkeley }\end{array}$ \\
\hline $\begin{array}{l}118 \text { Hagerstown subsoil } \\
\text { 123 Huntington silt loam } \\
125 \text { Huntington silt loam } \\
\text { 801 Huntington silt loam } \\
143 \text { Lehew loam }\end{array}$ & $\begin{array}{l}3.97 \\
2.56 \\
1.76 \\
3.03 \\
1.68\end{array}$ & $\begin{array}{l}0.127 \\
0.148 \\
0.102 \\
0.063 \\
0.057\end{array}$ & $\begin{array}{l}3.20 \\
5.76 \\
5.80 \\
2.07 \\
3.40\end{array}$ & $\begin{array}{l}\text { Berkeley } \\
\text { Marshall } \\
\text { Mason } \\
\text { Berkeley } \\
\text { Hampshire }\end{array}$ \\
\hline $\begin{array}{l}\text { 143A Lehew channery fine sandy } \\
\text { loam } \\
\text { 143B Lehew loam } \\
\text { 148 Litz shaly silt loam } \\
\text { 149 Litz shaly silt loam } \\
169 \text { Moshannon silt loam }\end{array}$ & $\begin{array}{l}0.53 \\
0.69 \\
0.92 \\
0.84 \\
1.60\end{array}$ & $\begin{array}{l}0.054 \\
0.055 \\
0.021 \\
0.034 \\
0.090\end{array}$ & $\begin{array}{r}10.26 \\
7.97 \\
2.28 \\
4.02 \\
5.66\end{array}$ & $\begin{array}{l}\text { Hampshire } \\
\text { Hampshire } \\
\text { Mercer } \\
\text { Monroe } \\
\text { Wirt }\end{array}$ \\
\hline
\end{tabular}

*Sperow, C. B., The Molybdenum Content of West Virginia Soils. West Virginia University Agricultural Experiment Station Bulletin 443, August, 1960. 


\begin{tabular}{|c|c|c|c|c|c|}
\hline & $\begin{array}{c}\text { LABORATORY NUMBER AND } \\
\text { SOIL TYPE }\end{array}$ & $\begin{array}{c}\text { TOTAL } \\
\text { MOLYBDENUM } \\
\text { PPM }\end{array}$ & $\begin{array}{l}\text { AVAIL } \\
\text { MOLYBD } \\
\text { PPM PER }\end{array}$ & $\begin{array}{l}\text { ABLE } \\
\text { DENUM } \\
\text { R CENT }\end{array}$ & COUNTY \\
\hline $\begin{array}{l}170 \\
174 \\
175 \\
176 \\
186\end{array}$ & $\begin{array}{l}\text { Moshannon silt loam } \\
\text { Muskingum silt loam } \\
\text { Muskingum silt loam } \\
\text { Muskingum silt loam } \\
\text { Pope sandy loam }\end{array}$ & $\begin{array}{l}1.25 \\
1.39 \\
1.08 \\
1.36 \\
0.85\end{array}$ & $\begin{array}{l}0.114 \\
0.101 \\
0.070 \\
0.065 \\
0.069\end{array}$ & $\begin{array}{l}9.13 \\
7.27 \\
6.48 \\
4.77 \\
8.12\end{array}$ & $\begin{array}{l}\text { Jackson } \\
\text { Kanawha } \\
\text { Boone } \\
\text { Raleigh } \\
\text { Lincoln }\end{array}$ \\
\hline $\begin{array}{l}187 \\
188 \\
208 \\
210 \\
210\end{array}$ & $\begin{array}{l}\text { Pope sandy loam } \\
\text { Pope gravelly silt loam } \\
\text { Teas silt loam } \\
\text { Teas silt loam } \\
\text { Teas subsoil }\end{array}$ & $\begin{array}{l}0.99 \\
1.50 \\
1.29 \\
0.93 \\
1.15\end{array}$ & $\begin{array}{l}0.097 \\
0.126 \\
0.064 \\
0.070 \\
0.178\end{array}$ & $\begin{array}{r}9.80 \\
8.40 \\
4.95 \\
7.53 \\
15.48\end{array}$ & $\begin{array}{l}\text { Upshur } \\
\text { Preston } \\
\text { Summers } \\
\text { Randolph } \\
\text { Randolph }\end{array}$ \\
\hline $\begin{array}{l}211 \\
212 \\
213 \\
214\end{array}$ & $\begin{array}{l}\text { Teas silt loam } \\
\text { Tilsit silt loam } \\
\text { Tilsit silt loam } \\
\text { Tilsit silt loam } \\
\text { Ungers loam }\end{array}$ & $\begin{array}{l}1.52 \\
1.55 \\
1.40 \\
1.24 \\
0.98\end{array}$ & $\begin{array}{l}0.145 \\
0.132 \\
0.055 \\
0.041 \\
0.124\end{array}$ & $\begin{array}{r}9.53 \\
8.52 \\
3.93 \\
3.32 \\
12.63\end{array}$ & $\begin{array}{l}\text { Preston } \\
\text { Mason } \\
\text { Wayne } \\
\text { Mercer } \\
\text { Tucker }\end{array}$ \\
\hline $\begin{array}{l}222 \\
154 \\
155 \\
156 \\
233\end{array}$ & $\begin{array}{l}\text { Upshur clay loam } \\
\text { Upshur-Gilpin silty clay } \\
\text { Upshur-Muskingum silty clay } \\
\text { Upshur-Muskingum clay } \\
\text { Wellston fine sandy loam }\end{array}$ & $\begin{array}{l}1.93 \\
1.76 \\
1.40 \\
2.30 \\
0.74\end{array}$ & $\begin{array}{l}0.071 \\
0.057 \\
0.060 \\
0.084 \\
0.029\end{array}$ & $\begin{array}{l}3.66 \\
3.22 \\
4.32 \\
3.66 \\
3.92\end{array}$ & $\begin{array}{l}\text { Jackson } \\
\text { Wirt } \\
\text { Jackson } \\
\text { Wayne } \\
\text { Wayne }\end{array}$ \\
\hline $\begin{array}{l}235 \\
237 \\
239 \\
240\end{array}$ & $\begin{array}{l}\text { Wellston subsoil } \\
\text { Westmoreland silt loam } \\
\text { Westmoreland silt loam } \\
\text { Wharton silt loam } \\
\text { Wharton silt loam }\end{array}$ & $\begin{array}{l}1.07 \\
3.14 \\
2.78 \\
2.44 \\
1.30\end{array}$ & $\begin{array}{r}0.087 \\
>1.000 \\
0.260 \\
0.330 \\
0.129\end{array}$ & $\begin{array}{r}8.16 \\
\\
9.34 \\
13.52 \\
9.89\end{array}$ & $\begin{array}{l}\text { Wayne } \\
\text { Ohio } \\
\text { Marion } \\
\text { Marshall } \\
\text { Nicholas }\end{array}$ \\
\hline $\begin{array}{l}241 \\
243 \\
245 \\
251 \\
253\end{array}$ & $\begin{array}{l}\text { Wharton silt loam } \\
\text { Wheeling silt loam } \\
\text { Wheeling silt loam } \\
\text { Zoar silt loam } \\
\text { Zoar silt loam }\end{array}$ & $\begin{array}{l}2.70 \\
1.96 \\
1.30 \\
1.30 \\
2.91\end{array}$ & $\begin{array}{l}0.202 \\
0.415 \\
0.088 \\
0.091 \\
0.202\end{array}$ & $\begin{array}{r}7.48 \\
21.16 \\
6.76 \\
7.02 \\
6.95\end{array}$ & $\begin{array}{l}\text { Preston } \\
\text { Wetzel } \\
\text { Mason } \\
\text { Wirt } \\
\text { Nicholas }\end{array}$ \\
\hline
\end{tabular}





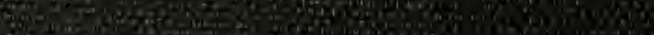

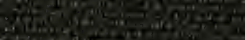

and

How

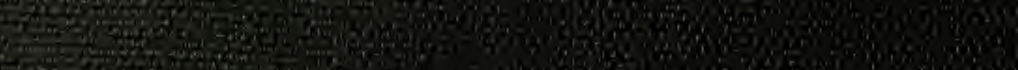

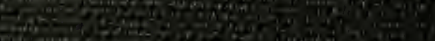

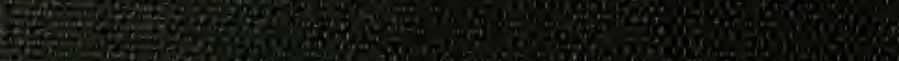

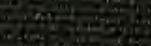

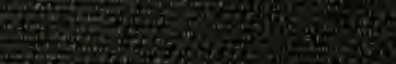

tot

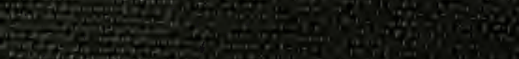

act

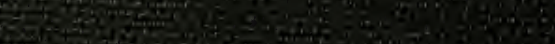

300.

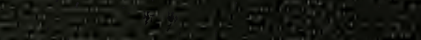

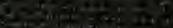

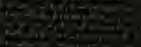

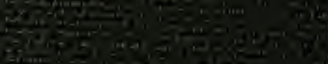

$20=x^{2}-10$ 